\title{
Necrotizing autoimmune myopathy with tubular aggregates
}

Nicolas N. Madigan, MBBCh, PhD, Teerin Liewluck, MD, Margherita Milone, MD, PhD, and Elie Naddaf, MD Neurology ${ }^{\circledR}$ 2019;93:313-314. doi:10.1212/WNL.0000000000007952

The formation of tubular aggregates (TA) within muscle fibers has been associated with toxic, metabolic, and hereditary myopathies, congenital myasthenic syndromes (CMS), ${ }^{1}$ and recently with pembrolizumab-associated myopathy. ${ }^{2}$ On electron microscopy, TA have the appearance of parallel tubules in crystalline arrangements, and are continuous extensions of the sarcotubular membrane system. ${ }^{1}$ TA have not been reported in necrotizing autoimmune myopathy associated with 3-hydroxy-3-methyl-glutaryl-CoA reductase (HMGCR) antibodies. A 60-year-old man experienced muscle pain and cramping within 18 months of initiating statin treatment, followed by bilateral proximal lower limb and hand grip weakness that progressed over 8 months. Creatine kinase (CK) was 18,674 U/L (normal $<250$ ), and anti-HMGCR antibodies were $>200$ units (normal $<20$ ). The quadriceps muscle biopsy is shown in the figure. Repetitive nerve stimulation showed no decrement. Next-generation sequencing of 166 myopathy/CMS genes, including those associated with TA, demonstrated no pathogenic variants. IV immunoglobulin therapy led to clinical improvement and normalization of $\mathrm{CK}$.

Figure Quadriceps muscle biopsy with tubular aggregates and necrotizing myopathy

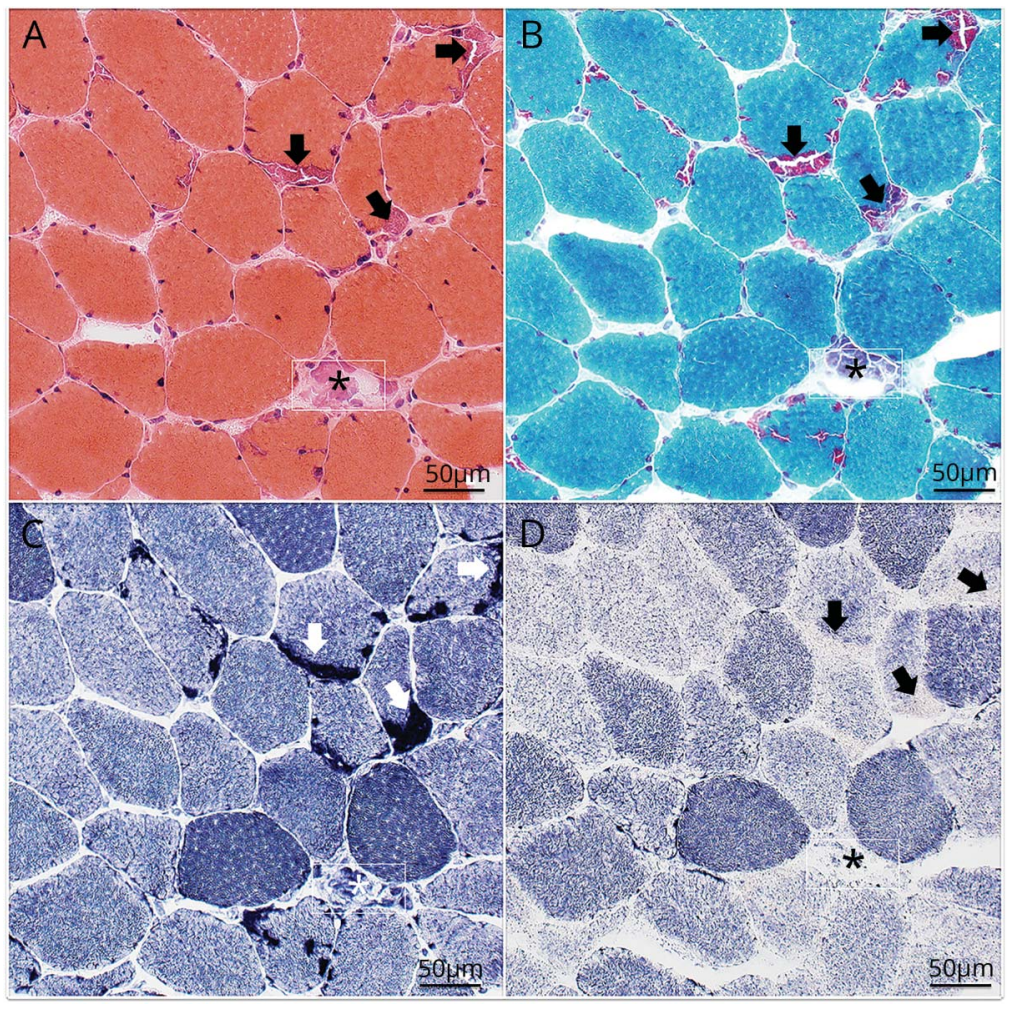

(A-D) Quadriceps muscle biopsy showed subsarcolemmal tubular aggregates (arrows) and scattered necrotic fibers (asterisk). Aggregates are (A) basophilic on hematoxylin \& eosin; (B) fuchsinophilic on trichromestained sections; (C) confined to type 2 fibers, and overreacting to NADH dehydrogenase; (D) but not to succinate dehydrogenase, indicating their sarcoplasmic reticulum rather than mitochondrial origin.

\author{
Correspondence \\ Dr. Naddaf \\ naddaf.elie@mayo.edu
}




\section{Study funding}

No targeted funding reported.

\section{Disclosure}

N. Madigan and T. Liewluck report no disclosures relevant to the manuscript. M. Milone receives research support from Mayo Clinic benefactors and compensation as associate editor of Neurology Genetics. E. Naddaf reports no disclosures relevant to the manuscript. Go to Neurology.org/ $\mathrm{N}$ for full disclosures.

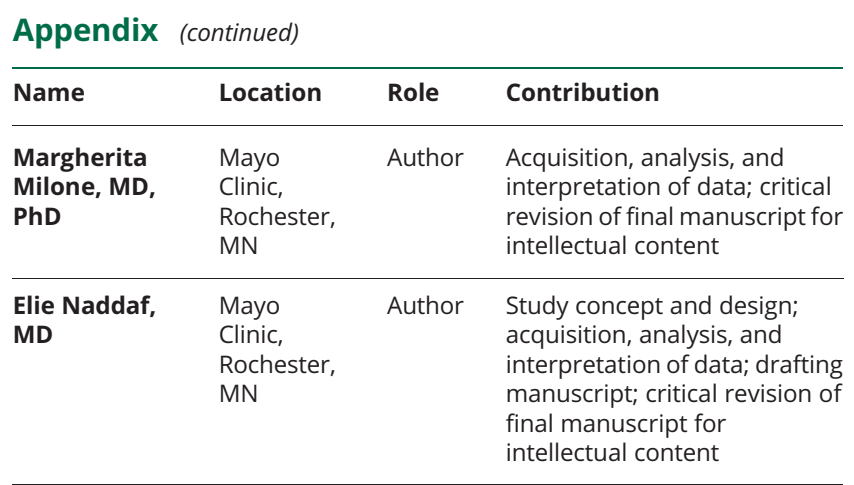

Appendix Authors

\begin{tabular}{|c|c|c|c|}
\hline Name & Location & Role & Contribution \\
\hline $\begin{array}{l}\text { Nicolas N. } \\
\text { Madigan, } \\
\text { MBBCh, PhD }\end{array}$ & $\begin{array}{l}\text { Mayo } \\
\text { Clinic, } \\
\text { Rochester, } \\
\text { MN }\end{array}$ & Author & $\begin{array}{l}\text { Study concept and design; } \\
\text { acquisition, analysis, and } \\
\text { interpretation of data; drafting } \\
\text { manuscript; critical revision of } \\
\text { final manuscript for } \\
\text { intellectual content }\end{array}$ \\
\hline $\begin{array}{l}\text { Teerin } \\
\text { Liewluck, MD }\end{array}$ & $\begin{array}{l}\text { Mayo } \\
\text { Clinic, } \\
\text { Rochester, } \\
\text { MN }\end{array}$ & Author & $\begin{array}{l}\text { Acquisition, analysis, and } \\
\text { interpretation of data; critical } \\
\text { revision of final manuscript for } \\
\text { intellectual content }\end{array}$ \\
\hline
\end{tabular}

\section{References}

1. Schiaffino S. Tubular aggregates in skeletal muscle: just a special type of protein aggregates? Neuromuscul Disord 2012;22:199-207.

2. Onda A, Miyagawa S, Takahashi N, et al. Pembrolizumab-induced ocular myasthenia gravis with anti-titin antibody and necrotizing myopathy. Intern Med 2019;58: $1635-1638$.

\section{The AAN is Fighting for You!}

In the midst of rapid changes in health care policy, the AAN has your back. From actively lobbying members of Congress to meeting with regulators to underscore the value of neurology and your services to your patients, the Academy is forcefully countering any threats to your profession and patient access to care. Learn more at AAN.com/policy-and-guidelines/advocacy, read the bimonthly Capitol Hill Report and monthly AANnews ${ }^{\circledR}$ member magazine, and respond to Advocacy Action Alert emails when we invite you to share your voice with Congress.

\section{Disputes \& Debates: Rapid online correspondence}

The editors encourage comments on recent articles through Disputes \& Debates:

Access an article at Neurology.org/ $N$ and click on "COMMENT" beneath the article header. Responses will be posted within 3 business days.

Before submitting a comment to Disputes \& Debates, remember the following:

- Disputes \& Debates is restricted to comments about studies published in Neurology within the last eight weeks

- Read previously posted comments; redundant comments will not be posted

- Your submission must be 200 words or less and have a maximum of five references; reference one must be the article on which you are commenting

- You can include a maximum of five authors (including yourself) 


\section{Neurology}

\section{Necrotizing autoimmune myopathy with tubular aggregates \\ Nicolas N. Madigan, Teerin Liewluck, Margherita Milone, et al.}

Neurology 2019;93;313-314

DOI 10.1212/WNL.0000000000007952

This information is current as of August 12, 2019

\begin{tabular}{|c|c|}
\hline $\begin{array}{l}\text { Updated Information \& } \\
\text { Services }\end{array}$ & $\begin{array}{l}\text { including high resolution figures, can be found at: } \\
\text { http://n.neurology.org/content/93/7/313.full }\end{array}$ \\
\hline References & $\begin{array}{l}\text { This article cites } 2 \text { articles, } 0 \text { of which you can access for free at: } \\
\text { http://n.neurology.org/content/93/7/313. full\#ref-list- } 1\end{array}$ \\
\hline Subspecialty Collections & $\begin{array}{l}\text { This article, along with others on similar topics, appears in the } \\
\text { following collection(s): } \\
\text { All Neuromuscular Disease } \\
\text { http://n.neurology.org/cgi/collection/all_neuromuscular_disease } \\
\text { Autoimmune diseases } \\
\text { http://n.neurology.org/cgi/collection/autoimmune_diseases } \\
\text { Muscle disease } \\
\text { http://n.neurology.org/cgi/collection/muscle_disease }\end{array}$ \\
\hline Permissions \& Licensing & $\begin{array}{l}\text { Information about reproducing this article in parts (figures,tables) or in } \\
\text { its entirety can be found online at: } \\
\text { http://www.neurology.org/about/about_the_journal\#permissions }\end{array}$ \\
\hline Reprints & $\begin{array}{l}\text { Information about ordering reprints can be found online: } \\
\text { http://n.neurology.org/subscribers/advertise }\end{array}$ \\
\hline
\end{tabular}

Neurology ${ }^{\circledR}$ is the official journal of the American Academy of Neurology. Published continuously since 1951, it is now a weekly with 48 issues per year. Copyright @ 2019 American Academy of Neurology. All rights reserved. Print ISSN: 0028-3878. Online ISSN: 1526-632X.

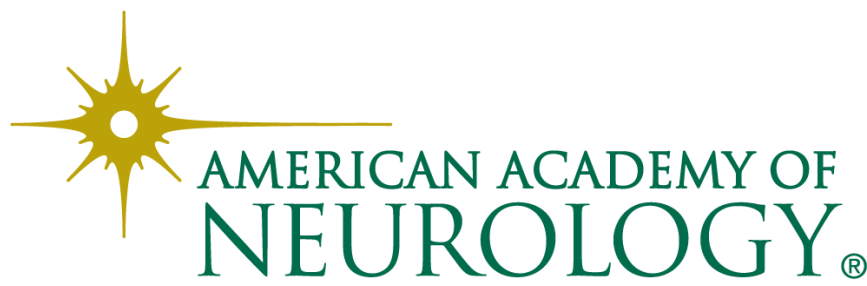

